\title{
BIO-IMAGING IN OUR KITCHENS: TO THE DISCOVERY OF PRODUCTS OF ANIMAL ORIGIN
}

\author{
SILVIA CLOTILDE MODINA (*), CRISTIAN BERNARDI $(*)$, \\ ERMINIO TREVISI (**), GRAZIA PASTORELLI (***), \\ MAURO DI GIANCAMILLO (***)
}

\begin{abstract}
SuNTO. - La crescente domanda di un controllo sempre più accurato degli alimenti ha spinto la ricerca verso l'impiego di tecniche rapide, precise e non distruttive in grado di garantire la presenza sul mercato di prodotti sicuri e di elevata qualità. Per questo scopo le industrie alimentari hanno affiancato alle comuni analisi chimico-fisiche metodiche di diagnostica per immagini, come l'imaging spettrale, la risonanza magnetica (RM) e la tomografia computerizzata (TC). L'imaging viene impiegato per valutare la struttura di prodotti carnei e ittici e per monitorare i cambiamenti che avvengono durante la loro lavorazione e stagionatura, come dimostrato, per esempio, da TC e RM nella caratterizzazione di salumi tipici della tradizione italiana. Nei nostri studi, TC e RM sono state impiegate per valutare la qualità di alcuni prodotti alimentari di eccellenza di origine animale. La TC ha dimostrato, in modo rapido e non distruttivo, il grado d'infiltrazione di tessuto adiposo in tagli carnei, freschi e congelati, destinati alla produzione di bresaola, consentendo di selezionare a priori i tagli più "magri" e quindi idonei alla commercializzazione di prodotti di buona qualità e ottimizzando i tempi di lavorazione. I dati ottenuti sono stati confermati da analisi istologiche e biochimiche condotte su campioni isolati. Analisi simili, applicate al prosciutto DOP Parma e al Prosciutto Nero di Parma hanno permesso di caratterizzare i due prodotti in base alla sede e alla quantità di tessuto adiposo, definendone la qualità. La RM ha permesso di differenziare i tranci di pesce spada (Xiphias gladius) di elevata qualità da quelli di squalo mako/smeriglio (Isurus oxyrbincus) di qualità inferiore, valutando forma e posizione del muscolo di Vogt. Questo aspetto è
\end{abstract}

(*) Dipartimento di Scienze Veterinarie per la Salute, la Produzione Animale e la Sicurezza Alimentare, Università degli Studi di Milano, Italia.

E-mail: silvia.modina@unimi.it

${ }^{(* *)}$ Dipartimento di Scienze Animali, della Nutrizione e dell'allevamento, Facoltà di Scienze Agrarie, Alimentari e Ambientali, Università Cattolica del Sacro Cuore, Piacenza, Italia.

${ }^{(* * * *)}$ Dipartimento di Medicina Veterinaria, Università degli Studi di Milano, Italia. 
particolarmente importante nella commercializzazione di specie ittiche di grossa mole vendute in tranci e per questo motivo difficilmente distinguibili dal consumatore che può incorrere in frodi alimentari a sua insaputa.

$* * *$

ABSTRACT. - The growing demand for real-time monitoring of food products has encouraged the use of rapid, accurate and non-destructive techniques, which are able to guarantee safe and high quality products on the market. In recent years, industries have invested in image diagnostic techniques (IDT), such as spectral and hyperspectral imaging, magnetic resonance imaging (MRI) and computed tomography (CT). These techniques are frequently used to evaluate the structure and microstructure of meat and fish products, and/or to monitor the changes that occur during their processing and ripening. Recently IDT have been successfully applied to the evaluation of cured meats of the Italian tradition. With our research we visualize the marbling of both fresh and frozen bovine cuts of meat intended for the production of "Bresaola" by CT in parallel with histological and biochemical analyses. CT allowed selecting in a quick nondestructive way the "leanest" cuts of meat, to be used for the production of good quality Bresaola and to optimize the processing times. Similar analyses have been applied to Parma ham and "Nero di Parma" to characterize the two dry-cured hams on the basis of the quali-quantitative levels of adipose tissue infiltrates. Finally, by IDT we identified big fishes when marketed as slices. Using MRI we demonstrated that it is possible to distinguish the swordfish (Xiphias gladius) from the mako shark (Isurus oxyrhincus) slices, by the position of Vogt muscle: this allows to reduce the sales of low quality commercial products (mako shark), instead of high quality ones (swordfish), to protect consumers and limit commercial frauds.

\section{INTRODUCTION}

Food industries play a critical role for human life, as food products are directly linked to society development and people's health. In the modern society, with a growing request for a high-quality life, as a global issue, food safety and quality are receiving increasing attention in both developed and developing countries. In this contest, it is critical for the industry not only to develop rapid, reliable and appropriated techniques to manipulate and preserve food products in order to guarantee consumers safe and high quality food (Erikson et al., 2012; Leygonie et al., 2012; Wang et al., 2016; Zhan et al., 2017; Bosse Nee Danz et al., 2018), but also to set up simple, precise, rapid, non-destructive and possibly on-line protocols for quality and safety evaluation.

The most common conventional methods available for food product evaluation and qualitative analysis, the enzyme-linked immuneabsorbent assay and polymerase chain reaction chromatography meth- 
ods (Santiago-Felipe et al., 2014), and the high-performance liquid chromatography (Elbashir and Aboul-Enein, 2018), gas chromatography and gas chromatography-mass spectrometry (Spanik and Machynakova, 2018) are generally off-line and destructive in nature. In addition, most of these methods are time-consuming and require very accurate sampling, sophisticated laboratory facilities, high-quality operators and a great amount of chemical reagents.

In recent years, non-destructive analytical techniques including imaging and spectroscopy have been gradually developed by the food industry for qualitative and quantitative analysis of various compounds. Among these techniques, hyperspectral imaging, computed tomography and magnetic resonance imaging are frequently use for the analyses of meat and fish cuts and the products derived from their processing (He et al., 2015; Reis et al., 2018; Scholz et al., 2015).

\section{IMAGING FOR MEAT AND FISH PRODUCTS}

Hyperspectral imaging (HIS) is one of the most promising techniques currently investigated for food quality (Liu et al., 2017; Ma et al., 2016). It is a fast, reagent-less, non-destructive analytical technique that combines conventional digital imaging and traditional spectroscopy into a unique system that allows to simultaneously obtain spatial and spectral data from the sample of interest. Spectroscopy identifies or quantifies the compounds on the basis of their spectral signature; imaging traduces this information into bi- or three-dimensional images for spatial visualization (Marshall, 2011). HIS is a powerful technique for the detection of contaminants, adulteration and authenticity of meat, poultry and fish products and creating chemical images to display the maps of the distribution of the constituents in a direct and easy way (Kamruzzaman et al., 2015).

Computed tomography (CT) is based on the principle of attenuation of an electromagnetic wave. This technique combines a large quantity of X-ray projection images and provides $3 \mathrm{D}$ images of the internal structures of the examined materials with spatial gradients in density. CT has strong penetrating power, high resolution, fast detection and intuitive results, which indicates advantages in food non-destructive analysis (Wang et al., 2018). For this reason it has been suggested as an alternative approach to provide very precise predictions of cuts compo- 
sition, intramuscular fat content at a lower cost than the reference procedures (dissection, chemical analysis), without damaging or reducing the value of the product of meat cuts, as demonstrated for beef (Prieto et al., 2010), lamb (Lambe et al., 2017) and pig products (Font-iFurnols et al., 2015).

Interesting information has been obtained with micro-CT $(\mu \mathrm{CT})$ and CT in the evaluation of cured meat. Italian food industry produces a broad range of high quality cured meat products representing, in the last years, an increasing substantial share in the global food market. "Typical" products differentiate with regard to the origin of raw material, the biochemical composition and the processing protocol. Quality evaluation and control are often still performed manually, which is laborious, expensive, time consuming, subject to human error and discrepancy. Moreover, in some cases, it is based on empirical parameters and on the practical knowledge of the manufactures. A study performed on five different types of Italian salami (Milano, Ungherese, Modena, Norcinetto and Napoli) has demonstrated that fat spatial distribution and percentage can be easily assessed by $\mu \mathrm{CT}$, allowing to characterize and define their typical configurations (Frisullo et al., 2009). Developing an appropriate understanding of the spatial distribution and interface of food components is a key tool in producing foodstuffs with desired mechanical and organoleptic properties and, at the same time, to ensure high quality standards. It is well known in fact that structure and microstructure of food products influence their physical, textural and sensory characteristics.

CT has been largely employed to characterize dry-cured hams produced in Italy as well as in other country. In Italy, Parma ham is the main Consortium for the production of dry-cured ham labelled with Protected Designation of Origin (PDO). Dry-cured ham is an uncooked meat product of high sensory quality which is achieved through unique and highly appreciated sensory features, resulting from both the raw material and the traditional prolonged processing (18-24 months). Characteristics of fatty areas have been considered in relation to enhancement of ham quality (Carnier et al., 2004): wide fatty areas are a major defect which affects the acceptability of dry-cured ham by the consumer (Lo Fiego et al., 2000) and fat deposition within the ham affects the quality of the processed meat (Gandemer, 2002). Alongside the intensive pig farming carried out according to industrial criteria, an attractive tradition-related production is emerging: it concerns native breeds such as the "Nero di Parma". Animals are fed fresh grass, corn, 
barley and wheat, as well as broad beans, berries, roots and acorns. The characteristics of meat of "Nero di Parma" are linked to the presence of intramuscular fat: this is due to the ability to accumulate more subcutaneous fat between the muscle fibres compared to the white breeds (Jimenez-Colmenero et al., 2010). Fat plays an important role in the development of the chemical and sensorial characteristics of cured meat products (Pastorelli et al., 2003; Ventanas et al., 2007), and contributes to the meat nutritional value (Wood et al., 2008).

In order to better characterise the Nero di Parma ham and to identify possible structural differences with the Parma DOP, we compared the two products in a CT study. A local producer, within the same factory, provided the two hams in order to ensure the same production technology. Our investigations demonstrated that the Nero di Parma has a typical structure, since it differs in the distribution of lean and fat compared to the Parma DOP (Fig. 1). Moreover we found an opposite content of two components: Nero di Parma showed 39\% and $55 \%$ of lean and fat, whereas Parma DOP showed 59\% and 34\% respectively; connective content is similar (manuscript submitted).
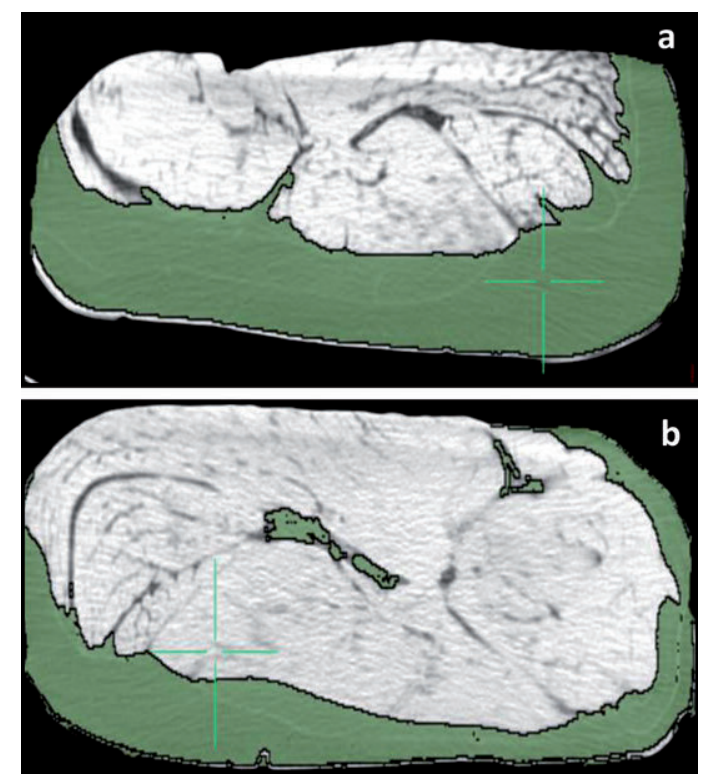

Fig 1. Representative image of CT automatic segmentation: 2.5-mm-thick slice of Nero di Parma ham (a) and Parma (DOP) ham (b): note the different distribution of fat (green area) and lean meat (white area). 
A CT investigation was also performed to evaluate the presence of fat and its distribution in another typical dry-cured Italian product, the "Bresaola": this is a salted and slightly aged meat product (from beef or horse) that can be consumed raw. It is cylindrical in shape and dark red in colour, with a delicate aroma and moderately savoury taste. "Bresaola della Valtellina" is produced exclusively with meat of cows certified as being at least 24 months old: it can be made with six different muscle masses from the tight, deprived of bones. The topside is "punta d'anca" the most precious part, characterized by a typical droplet shape and very low amount of fat among the muscle fibres. Bresaola della Valtellina is processed exclusively in the province of Sondrio and it is an IGP product since 1996, but meat cuts can be obtained from cattle raised and slaughtered in other Italian areas or imported from abroad (http://www.dop-igp.eu). Many meat cuts come from Brazil and Argentina. Meat cuts are usually imported frozen and directly processed as a whole without defrosting; therefore it is possible that they have a structure, in terms of lean and fatty substance, not in conformity with that foreseen for the final product, according to the established standards (no more than $7 \%$ of fat).

We demonstrated that CT is able to define the structure of a muscle even if it is frozen (Modina et al., 2015): indeed, it was possible to identify two different types of "punta d'anca", with low or high marbling, which made these cuts more or less useful for the production of cured meats such as Bresaola. Imaging results were confirmed by chemical and histological analyses performed on special region of interests, in order to quantify and morphologically define fat and lean presence and distribution. By considering the same parameters, CT proved to be an excellent, fast and accurate technique to evaluate also the final packaged product, at the end of ripening, without removing packaging (Fig. 2).

$\mathrm{CT}$ is also of special interest to monitor meat curing processes since a high density of salt ions produce a marked increase of CT attenuation values allowing to follow salt diffusion and distribution during the whole process. For this reason CT has been applied to monitor the production of Norwegian (Haseth et al., 2012) and Iberian dry-cured ham (Fulladosa et al., 2010).

Similar studies have been performed by using Magnetic Resonance Imaging (MRI). This technique is the imaging modality of high-resolution Nuclear Magnetic Resonance (NMR). It provides a very high spatial signal response from magnetic nuclei, such as protons, in 
magnetic fields to generate $3 \mathrm{D}$ structure images. MRI is extensively used in clinical radiology, especially to acquire soft tissue images for diagnostic purposes. Recently food industries have investigated the use of MRI and are continuously developing applications to food analysis and food processing (Marcone et al., 2013). Combined with computer vision techniques, MRI has been proposed as an alternative or complementary method to define the sensory characteristics of dry-cured loins in a non-destructive manner (Caballero et al., 2017).
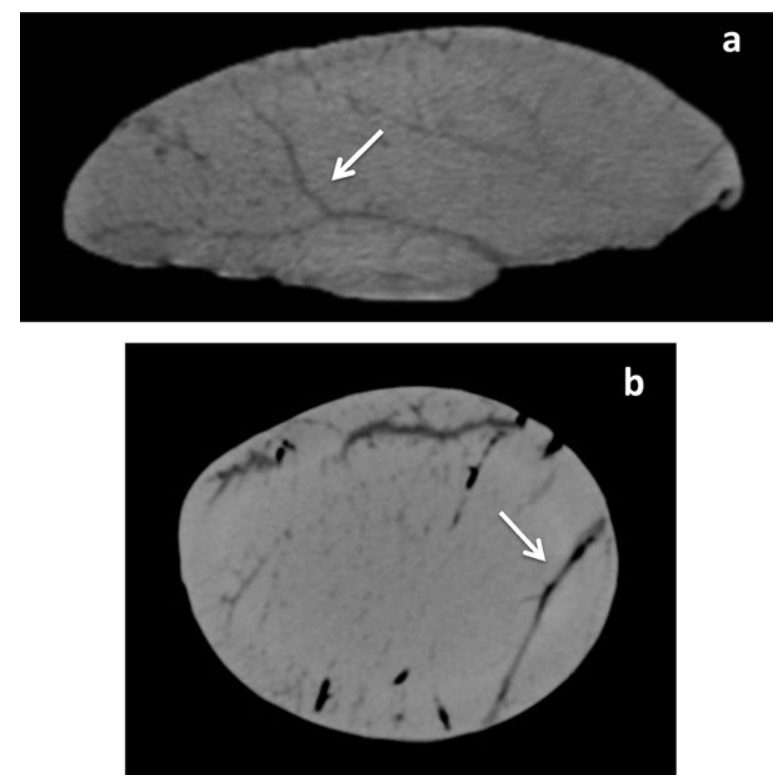

Fig. 2. CT of 2.5-mm-thick slices of "punta d'anca" (a) and Bresaola (b): adipose tissue appears as dark linear area infiltrating the frozen muscle and the cure product (arrows).

A multi-parametric magnetic resonance microscopy has been employed for discrimination among different processing procedures and anatomical compartments of Slovenian dry-cured hams (Bajd et al., 2016a). The same study has been repeated by using the quantitative magnetization transfer magnetic resonance. Results achieved by this innovative, though poorly used for food analyses as very expensive, technique indicate that some of the new parameters might be useful equally well or even better as the conventional MRI parameters to analyze dehydration during the processing of dry-curing meat tissue (Bajd et al., 2016b). 
Regarding Italian products, MRI has successfully been used to monitor local microstructural changes of Parma DOP dry-cured hams during their processing. With this technique it was possible to evaluate changes in salt and moisture content, marbling fat quantity and distribution, and the formation of the external coats, i.e. modifications that as a whole may greatly influence the physical, textural and sensory properties of the final products (Fantazzini et al., 2009).

NMR is considered a valid technique to identify gross anatomy, diffusion processes, temperature profiles, structure of tissues, as well as distribution of components such as fat, water and salt also in fish as a whole and in fish-derived products (Erikson et al., 2012).

Consumption of seafood has considerably increased in recent years as an alternative to livestock consumption. However a sustainable and fair fish market is threatened by seafood mislabelling, which may result from commercial fraud or human error. Sales of fish fillets 'steaks' and slices are in constant increase as they appeal to consumers of all ages. Since the fish species in such preparations cannot easily be identified by non-experts, the risk exists that fish of high commercial value may fraudulently be substituted with fish of low value. Fishes have white and red muscle: white muscles are poorly vascularized and have fibres of larger diameter compared to red muscles which are heavily vascularized and have higher myoglobin contents. The anatomical study of red muscle (Vogt's muscle) can be a suitable approach to identify the species of big fishes, such as the Swordfish (Xipbias gladius), lamnid sharks (family Lamnidae), Mediterranean spearfish or Atlantic blue marlin (family Isthiophoridae) and tunas (family Scombridae) in which the position and shape of red muscle is species-specific. In swordfish, red muscle has an anchor shape and sits in the middle of white muscle, while in blue marlin it locates immediately under the skin. In lamnid sharks and tunas, red muscle is found deep in the body with a different shape along the vertebral column. This parameter is considered a useful tool for commercially distinguish these species in the food market.

The fish muscular anatomy has often been studied with the conventional method of serial, transverse sectioning of specimen with the complete lost of sample. Several studies indicated that MRI offers a unique opportunity to produce cross-section images without damaging the whole fish, the fillets or the processed fish products. MRI was first applied in anatomical studies of aquatic organisms by Blackband and 
Stoskopf (1990); afterward, some studies on fish quality were performed on the soft-flesh of the rainbow trout (Foucat et al., 2004) and on the belly bursting in herring (Veliyulin et al., 2007). An earlier MRI study on sharks (Waller et al., 1994) demonstrated the capability of this technique to qualitatively contrast images of cartilage and various soft tissues in organs including the brain, the digestive tract, and muscles. In our study we demonstrated that MRI is a suitable tool to identify and quantify the red muscle position and volume in the mako shark (Isurus oxyrinchus), a big fish that is often marketed instead of finest fish such as the swordfish and tuna (Fig. 3).

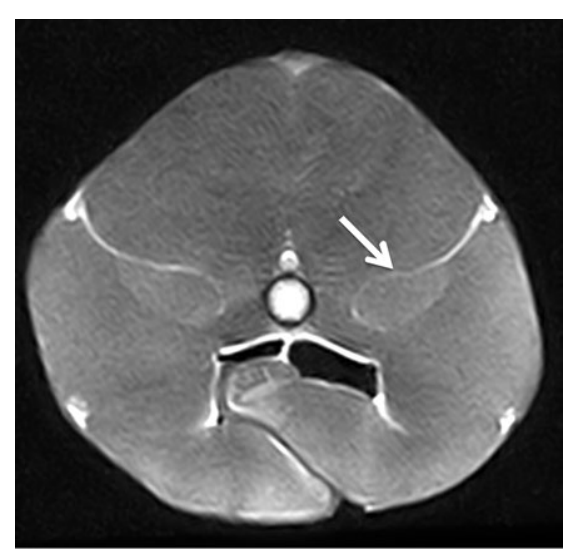

Fig. 3. MRI of a $10 \mathrm{~mm}$ slice of mako shark: Vogt muscle is well-recognizable in T2-weighted image: position and shape of the muscle permit to easily identify the species (arrow).

\section{CONCLUSIONS AND FUTURE PERSPECTIVES}

Meat and fish food quality, safety and authenticity are becoming dynamic and challenging concerns, which require the creation of new information and of continuous update of the current knowledge to meet market's requests by guaranteeing high quality standards and the prevention of risks to human health.

Development and upgrade of non-contact, non-destructive, rapid, accurate, and efficient analytical tools for quality assessment is therefore absolutely mandatory for the food industries; in this context, imaging techniques may represent the challenge for the future. 
Imaging techniques could be included in the production chain of the big food companies to check all steps of food production, from the slaughterhouse to the packaging and storage of the final products: this would significantly reduce time and costs for the quality control.

At the same time it is also desirable that new machines and new programs be developed to assess the quality of "typical products" such as Italian cured meats. In this globalization era, in fact, the opening of the markets has put at almost everybody's disposal a wide variety of foods (including "niche" food products from the Italian tradition) allowing everybody to taste food savors and aromas from different Countries. This is appreciable to expand the small industries markets, but at the same time it opens the way to produce counterfeit foods, which do not reflect the quality standards and the typical characteristics of the traditional products. Dedicated imaging techniques could be a valuable support for assessing and preserving key quality characteristics of the products, to guarantee authenticity and safety at the same time.

\section{REFERENCES}

Bajd F, Skrlep M, Candek-Potokar M, Vidmar J, Sersa I. Use of multiparametric magnetic resonance microscopy for discrimination among different processing protocols and anatomical positions of Slovenian dry-cured hams. Food Chem Pt B 2016a; 197:1093-101.

Bajd F, Skrlep M, Candek-Potokar M, Vidmar J, Sersa I. Application of quantitative magnetization transfer magnetic resonance imaging for characterization of $d r y$ cured hams. Meat Sci 2016b; 122:109-18.

Blackband SJ, Stoskopf MK. In vivo nuclear magnetic resonance imaging and spectroscopy of aquatic organisms. Magn Reson Imaging 1990; 8:191-8.

Bosse Nee Danz R, Muller A, Gibis M, Weiss A, Schmidt H, Weiss J. Recent advances in cured raw ham manufacture. Crit Rev Food Sci 2018; Nutr 58:610-30.

Caballero D, Antequera T, Caro A, Avila MDM, Perez-Palacios T. Non-destructive analysis of sensory traits of dry-cured loins by MRI-computer vision techniques and data mining. J Sci Food Agric 2017; 97: 2942-52.

Carnier P, Gallo L, Romani C, Sturaro E, Bondesan V. Computer image analysis for measuring lean and fatty areas in cross-sectioned dry-cured hams. J Anim Sci 2004; 82: 808-15.

Elbashir AA, Aboul-Enein HY. Application of gas and liquid chromatography coupled to time-of-flight mass spectrometry in pesticides: Multiresidue analysis; Biomed Chromatogr 2018; 32:1-7

Erikson U, Standal IB, Aursand IG, Veliyulin E, Aursand M. Use of NMR in fish processing optimization: a review of recent progress. Magn Reson Chem 2012; 50: 471-80. 
Fantazzini P, Gombia M, Schembri P, Simoncini N, Virgili R. Use of Magnetic Resonance Imaging for monitoring Parma dry-cured ham processing. Meat Sci 2009; 82:219-27.

Font-i-Furnols M, Carabus A, Pomar C, Gispert M. Estimation of carcass composition and cut composition from computed tomography images of live growing pigs of different genotypes. Animal 2015; 9:166-78.

Foucat L, Taylor RG, Labas R, Renou JP. Soft flesh problem in freshwater rainbow trout investigated by magnetic resonance imaging and histology. J Food Sci 2004; 69:FCT320-7.

Frisullo P, Laverse J, Marino R, Nobile MAD, Del Nobile MA. X-ray computed tomography to study processed meat microstructure. J Food Eng 2009; 94:283-9.

Fulladosa E, Santos-Garces E, Picouet P, Go P. Prediction of salt and water content in dry-cured hams by computed tomography. J Food Eng 2010; 96:80-5.

Gandemer G. Lipids in muscles and adipose tissues, changes during processing and sensory properties of meat products. Meat Sci 2002; 62:309-21.

Haseth TT, Sorheim O, Hoy M, Egelandsdal B. Use of computed tomography to study raw ham properties and predict salt content and distribution during dry-cured ham production. Meat Sci 2012;90:858-64.

He HJ, Wu D, Sun DW. Nondestructive spectroscopic and imaging techniques for quality evaluation and assessment of fish and fish products. Crit Rev Food Sci Nutr 2015; 55: 864-86.

Jimenez-Colmenero F, Ventanas J, Toldra F. Nutritional composition of dry-cured ham and its role in a bealthy diet. Meat Sci 2010; 84:585-93.

Kamruzzaman M, Makino Y, Oshita S. Non-invasive analytical technology for the detection of contamination, adulteration, and authenticity of meat, poultry, and fish: a review. Anal Chim Acta 2015; 853:19-29.

Lambe NR, McLean KA, Gordon J, Evans D, Clelland N, Bunger L. Prediction of intramuscular fat content using CT scanning of packaged lamb cuts and relationships with meat eating quality. Meat Sci 2017;123:112-9.

Leygonie C, Britz TJ, Hoffman LC. Impact of freezing and thawing on the quality of meat: review. Meat Sci 2012; 91:93-8.

Liu Y, Pu H, Sun D, Liu YW, Pu HB, Sun DW. Hyperspectral imaging technique for evaluating food quality and safety during various processes: a review of recent applications. Trends in Food Science \& Technology 2017; 69:25-35.

Lo Fiego DP, Virgili RMB, Tassone F, Pecoraio, Riverberi M, Russo V. Caratteristiche delle carcasse e dei tagli di differenti tipologie di suino pesante attualmente presenti sul mercato. Rivista suinicola 2000; 41:143.

Ma J, Sun DW, Qu JH, Liu D, Pu H, Gao WH, et al. Applications of Computer Vision for Assessing Quality of Agri-food Products: A Review of Recent Research Advances. Crit Rev Food Sci Nutr 2016; 56:113-27.

Marcone MF, Wang SA, Albabish W, Nie SP, Somnarain DAH. Diverse food-based applications of nuclear magnetic resonance (NMR) technology. Food Res Int 2013; 51:729-47.

Marshall S. Hyperspectral imaging technology. AWE International 2011; 1:9-15. 
Modina SC, Trevisi E, Bernardi C, Di Giancamillo M. Meat composition, from microscopy to chemistry by way of diagnostic imaging. Microscopie 2015; 24:2-34.

Pastorelli G, Magni S, Rossi R, Pagliarini E, Baldini P, Dirinck P, et al. Influence of dietary fat, on fatty acid composition and sensory properties of dry-cured Parma ham. Meat Sci 2003; 65:571-80.

Prieto N, Navajas EA, Richardson RI, Ross DW, Hyslop JJ, Simm G, et al. Predicting beef cuts composition, fatty acids and meat quality characteristics by spiral computed tomography. Meat Sci 2010; 86:770-9.

Reis MM, Van Beers R, Al-Sarayreh M, Shorten P, Yan WQ, Saeys W, et al. Chemometrics and hyperspectral imaging applied to assessment of chemical, textural and structural characteristics of meat. Meat Sci 2018;144:100-9.

Santiago-Felipe S, Tortajada-Genaro LA, Puchades R, Maquieira A. Recombinase polymerase and enzyme-linked immunosorbent assay as a DNA amplification-detection strategy for food analysis. Anal Chim Acta 2014; 811:81-7.

Scholz AM, Bunger L, Kongsro J, Baulain U, Mitchell AD. Non-invasive methods for the determination of body and carcass composition in livestock: dual-energy X-ray absorptiometry, computed tomography, magnetic resonance imaging and ultrasound: invited review. Animal 2015; 9:1250-64.

Spanik I, Machynakova A. Recent applications of gas chromatography with high-resolution mass spectrometry. J Sep Sci 2018; 41:163-79.

Veliyulin E, Felberg HS, Digre H, Martinez I. Non-destructive nuclear magnetic resonance image study of belly bursting in herring (Clupea harengus). Food Chem 2007; 101:1545-51.

Ventanas S, Ventanas J, Tovar J, Garcia C, Estevez M. Extensive feeding versus oleic acid and tocopherol enriched mixed diets for the production of Iberian dry-cured hams: effect on chemical composition, oxidative status and sensory traits. Meat Sci 2007; 77:246-56.

Waller GNH, Williams SCR, Cookson MJ, Kaldoudi E. Preliminary analysis of elasmobranch tissue using magnetic resonance imaging. Magn Reson Imaging 1994; 12:535-9.

Wang CY, Huang HW, Hsu CP, Yang BB. Recent Advances in Food Processing Using High Hydrostatic Pressure Technology. Crit Rev Food Sci Nutr 2016; 56:527-40.

Wang Z, Herremans E, Janssen S, Cantre D, Verboven P, Nicolai B. Visualizing 3D Food Microstructure Using Tomographic Methods: Advantages and Disadvantages. Annu Rev Food Sci Technol 2018; 9:323-43.

Wood JD, Enser M, Fisher AV, Nute GR, Sheard PR, Richardson RI, et al. Fat deposition, fatty acid composition and meat quality: a review. Meat Sci 2008; 78: 343-58.

Zhan X, Sun DW, Zhu Z, Wang QJ. Improving the quality and safety of frozen muscle foods by emerging freezing technologies: A review. Crit Rev Food Sci Nutr 2017; $1-14$. 